\title{
Evolution of parathyroid hormone receptor family and their ligands in vertebrate
}

\author{
Jason S. W. On, Billy K. C. Chow and Leo T. O. Lee*
}

School of Biological Sciences, The University of Hong Kong, Hong Kong, China

\section{Edited by:}

Hubert Vaudry, University of Rouen,

France

\section{Reviewed by:}

Joao Carlos Dos Reis Cardoso University of Algarve, Portugal

James A. Carr, Texas Tech University, USA

\section{*Correspondence:}

Leo T. O. Lee, School of Biological

Sciences, The University of Hong

Kong, Pokfulam Road, Hong Kong,

China

e-mail: Itolee2@hku.hk
The presence of the parathyroid hormones in vertebrates, including PTH, PTH-related peptide (PTHrP), and tuberoinfundibular peptide of 39 residues (TIP39), has been proposed to be the result of two rounds of whole genome duplication in the beginning of vertebrate diversification. Bioinformatics analyses, in particular chromosomal synteny study and the characterization of the PTH ligands and their receptors from various vertebrate species, provide evidence that strongly supports this hypothesis. In this mini-review, we summarize recent advances in studies regarding the molecular evolution and physiology of the PTH ligands and their receptors, with particular focus on non-mammalian vertebrates. In summary, the PTH family of peptides probably predates early vertebrate evolution, indicating a more ancient existence as well as a function of these peptides in invertebrates.

Keywords: parathyroid hormone, parathyroid hormone receptor, evolution, vertebrate, G protein-coupled receptor
Although the physiological actions of parathyroid hormone family are well-documented in the literature, review about the molecular evolution of PTH ligands and their receptors are limited. Therefore, in this article, we reviewed recent studies about the PTH ligands and their receptors in different vertebrate species. We believe this mini-review can provide a better overview about the molecular evolution of this ligand and receptor family in vertebrate.

\section{PARATHYROID HORMONE FAMILY}

The parathyroid hormone peptide subfamily includes PTH, PTHrelated peptide (PTHrP), and tuberoinfundibular peptide of 39 residues (TIP39, also known as PTH2). These hormones are encoded in separate genes but their mature peptides share significant sequence homology within the first 34 amino acids. In humans, PTH is highly expressed and is secreted by the parathyroid gland, but lower levels of its transcript can also be detected in the hypothalamus, pituitary, and thymus (1-3). PTH is an important regulator for body calcium homeostasis. In contrast to $\mathrm{PTH}$, PTHrP is widely expressed in a broad spectrum of tissues, including central nervous system (4). The main function of PTHrP is the regulation of chondrocyte growth and differentiation in the growth plates of developing long bones (5). TIP39 shares a relatively lower level of sequence homology with PTH or PTHrP, but high resolution NMR studies suggest that it has a similar three-dimensional structure when compared to them (6). TIP39 is mainly synthesized in two brain regions, the subparafascicular area of the thalamus and the medial paralemniscal nucleus of the pons (7). Recent reports suggest that TIP39 is a neuroendocrine hormone that modulates several aspects of the stress response, as well as controls body temperature (8). In addition to PTH, PTHrP, and TIP39, there is a newly identified member of the family, PTH-like peptide (PTH-L), which is only present in non-mammalian species including Xenopus, teleosts, and chicken. pth-l gene structure is similar to that of the pth gene, but the mature peptide of PTH-L shares a higher level of sequence homology to PTHrP (9). The expression of PTH-L has been investigated in chicken and Xenopus. The peptide was found widely, but differentially expressed in various tissues of these organisms. Abundant PTH-L transcripts were detected in cartilage in chicken, and in brain, lung, and bone in Xenopus laevis (10). Although the physiological role has not yet been fully established, some reports have suggested that PTH-L in teleosts (Seabream) and X. laevis is the most potent calciotropic factor among all PTH peptides $(10,11)$.

\section{PTH RECEPTOR FAMILY}

The importance of the PTH system as a regulator to control blood calcium levels was recognized early in the 20th century by observing the correlation between the parathyroid gland and tetany (12, 13). However, understanding of the physiological function of PTH was not substantially developed until the discovery of the human PTH1R in 1991 (14). PTH1R is also called the PTH/PTHrP receptor because of its equal binding affinities for both PTH and PTHrP. Subsequently, PTH2R, with a ligand preference for PTH over PTHrP, was identified in humans (15). However, further investigations suggested that TIP39 is the native ligand of PTH2R because of the robust activation of human PTH2R by TIP39 and the poor activation of rat PTH2R by PTH (16). In the last two decades, due to the success of different genome projects, paralogs and orthologs of PTHRs have been identified from various vertebrate species. These studies have also led to the discovery of an additional member of the receptor family, PTH3R, which is found only in non-mammalian vertebrates. The ligand specificity and structure of PTH3R resemble PTH1R more than PTH2R (1719). In zebrafish, seabream, and chicken, PTH3R shows a stronger affinity for PTHrP than do other members of the PTH receptor family $(17,18,20)$.

\section{EVOLUTION OF PTH AND THE PTHR FAMILY}

The PTHRs belong to the class B1 G protein-coupled receptors (GPCRs). It is widely believed that the paralogs of PTHR, pth1r, 
$p$ th $2 r$, and $p$ th $3 r$ are evolved after two rounds of whole genome duplication (2WGD) (17, 21-23). Recent genome synteny comparison provided strong evidence to support this hypothesis (22). From teleosts to humans, PTHRs are found in three conserved loci. Interestingly, PTH2R and PTH3R are not found in birds and mammals, respectively. The genes for the PTHR cognate ligands ( $p$ th, pthrp, and tip39) are also located in three conserved loci and were likely generated through similar WGD events as their receptors. The $p$ th- $l$ gene is found in the fourth locus in chicken, which shares considerable synteny with the other three conserved loci of the $p$ th gene family. Specifically in teleost, the third WGD generate extra copies of $p t h$ ( $p$ th1 and $p t h 2$ ) and $p t h r p$ ( $p$ thrpA and $p t h r p B$ ), but whether the copies share the synteny with PTH gene family remains to be investigated $(11,24)$.

The elephant shark was diverged at the time point just after the vertebrate $2 \mathrm{WGD}$; therefore, its primitive genome provides insight into the evolution of the PTH and PTHR family $(25,26)$. Consistent with the " $4: 1$ rule" $(27,28)$, except for the loss of the fourth putative PTHR, all the homologs of PTH and the PTHR genes could be identified in elephant shark (hereafter abbreviated to "e") $(17,29)$. PTH, PTHrP, and putative ePTH-L (designated as $\mathrm{PTH} 2$ in the references) have already been cloned, while a putative tip39 gene was identified in the genome database $(17,29)$. Even though ePTH2 is phylogenetically grouped with other PTH-Ls, the identity of ePTH2 as an ortholog to fish PTH-L was questioned because the gene structure of $e P T H 2$ is different from teleost $p$ thl, but resembles other $p$ th genes. Elephant shark $p$ th 2 has its first intron before the KR cleavage site; whereas teleost $p$ th- $l$ genes do not contain this cleavage site, and instead have the first intron before the SRR motif (29). More importantly, ePTH2 is unable to stimulate cAMP production in PTH1R expressing cells, but teleost PTH-L appears to be a potent factor (29).

Regarding the evolution of PTH and the PTHR family in early vertebrates, hypotheses have been proposed largely based on bioinformatics data $(17,21,22,30)$. In lamprey, the distinct phylogenetic positions of the two deduced PTH-like receptors and hormones, suggested a possible scenario of PTHR/PTH evolution before 2WGD (17). PTH1R-like and PTH2R-like genes were produced after the first round of WGD. Then, after the divergence of lamprey, the second round of WGD resulted in only PTH3R due to the lost of the fourth receptor in the PTH2R lineage. For the ligands, PTHrP and TIP39 were proposed to be the pioneers of the PTH family, since they are present in agnathan genomes (18).

In invertebrates, PTHR-like genes are found in the genomes of protostomians, cephalochordates, and urochordates. This indicates the ancestral PTHR was evolved before the deuterostomeprotostome split $(21,22,30)$. Regarding the ligands, a recent bioinformatics approach has identified PTH-like peptides in tunicates and amphioxi (31). Even though the invertebrate peptides share relatively low homology to the vertebrate PTH family, these observations indicate that the PTH family of peptides already existed in cephalochordates.

\section{EVOLUTIONARY CHANGES IN GENE STRUCTURES OF THE PTH FAMILY}

After divergence from their last common ancestor, PTHrP exhibited more changes in gene structure than PTH. The classic gene structure of $p$ th contains three exons with the prepro-peptide are encoded in the last two exons. This gene structure is conserved from elephant shark to human $(10,24,29)$. However, the pthrp gene structure differs through vertebrates by the introduction of exons upstream and/or downstream of the mature peptide coding regions, and presence of splicing variants in Xenopus, chicken, and human $(10,32)$. In addition, unlike PTH and PTH-L, their precursor proteins that lead to single mature peptide, posttranslational processing of mammalian prepro-PTHrP can give rise to three mature peptides: PTHrP, middle region, and osteostatin (33, 34). The increase of pthrp gene structure complexity during vertebrate evolution may reflect changes in the physiological roles of this peptide, such as adaptation to the terrestrial environment in tetrapods $(9,35)$. The new member of the PTH family, PTH-L in non-mammalian vertebrates, was considered as an intermediate between PTH and PTHrP due to its independent phylogenetic position to both PTH and PTHrP $(10,11)$. Moreover, although the gene structure of PTH-L resembles that of PTH in fugu, chicken, and Xenopus, alternative transcripts were reported for Xenopus and chicken PTH-L. In addition, all investigated PTH-L peptides contain the "MHD" motif, which is the characteristic of teleost PTHrP (9-11). In elephant shark, all the PTH peptides possess the "MHD" motif (29), suggesting that this motif is present in the common ancestor of PTH peptides and was lost during evolution in some vertebrates. Among all PTH family members, the unique properties of TIP39 are shown by its distant position from other members in phylogenetic analysis, and by the lack of "MHD" or any similar motif $(36,37)$. The gene structure of TIP39 is highly conserved from mammals to teleosts, and like that of PTH, has three exons (37). The uniqueness of TIP39 could be a result of its earlier divergence from other members of the PTH family.

\section{LIGAND BINDING OF PTHRS IN VERTEBRATES}

Significant levels of sequence homology are found in the first 34 amino acids of mature PTHrP, PTH, and PTH-L peptides. This region is important for receptor binding and receptor activation $(9,10,16)$. In mammals, it has been shown that activation of PTH1R by $\mathrm{PTH}_{(1-34)}$ and $\mathrm{PTHrP}_{(1-34)}$ are comparable to that by the corresponding full length peptides $(38,39)$. The biological activity of $\mathrm{PTH}_{(1-34)}$ was indicated by administration of $\mathrm{PTH}_{(1-34)}$ to patients with osteoporosis, which resulted in enhanced bone development $(40,41)$. $\mathrm{PTH}_{(15-34)}$ are required for high affinity binding through interaction with the extracellular $\mathrm{N}$-terminal domain of the receptor $(42,43)$. Such functional division within PTH in receptor interaction is also likely for PTHrP and TIP39, as well as for interaction of PTH2R with PTH-like peptides, as shown by studies of ligand variants and chimeric receptors (4447). Functional testing using truncated $\operatorname{PTHrP}_{(2-34,3-34 \text {, and 7-34) }}$ indicated that these peptides were unable to trigger cAMP synthesis but could stimulate the PLC pathway. In summary, the first few residues are essential to the cAMP pathway but not for receptor binding (48). These properties of truncated $\mathrm{PTH}_{(7-34)}$ and $\mathrm{PTHrP}_{(7-36)}$ were utilized for developing antagonists of PTH1R (47).

Table 1 summarizes the ligand specificity of the PTHR family in various species. Human (hu) PTH1R can be activated by PTH and PTHrP with indistinguishable potency in downstream 
Table 1 | Ligand specificity of PTHR family.

\begin{tabular}{|c|c|c|c|c|}
\hline Receptor & Species & Assay & Ligand specificity & Reference \\
\hline \multirow[t]{13}{*}{ PTH1R } & Human & cAMP & $\mathrm{hPTHrP} \approx \mathrm{hPTH} \approx \mathrm{zPTH} 1 \approx \mathrm{zPTH} 2>\mathrm{fPTHrP}$, no response to TIP39 & $(14,24)$ \\
\hline & & PLC & $\mathrm{hPTHrP} \approx \mathrm{hPTH}$ & $(19)$ \\
\hline & & ERK1/2 & $\mathrm{hPTHrP} \approx \mathrm{hPTH}$ & $(51)$ \\
\hline & & IP1 & $\mathrm{hPTHrP} \approx \mathrm{hPTH}$ & $(51)$ \\
\hline & & Binding ${ }^{c}$ & $\mathrm{hPTHrP} \approx \mathrm{hPTH}$ & $(52)$ \\
\hline & Mouse & cAMP & hPTHrP $\approx$ hPTH, no response to TIP39 & $(50)$ \\
\hline & Rat & cAMP & rPTHrP $\approx$ rPTH, no response to TIP39 & $(16)$ \\
\hline & Chicken & cAMP & cPTHrP $\approx$ hPTH $>$ cPTH-L $>$ cPTH & $(17)$ \\
\hline & & PLC & cPTHrP, slight stimulation by $\mathrm{cPTH}-\mathrm{L}$ and no response to and $\mathrm{CPTH}$ & $(17)$ \\
\hline & Zebrafish & cAMP & $\mathrm{hPTH} \approx \mathrm{hPTHrP} \approx \mathrm{fPTHrPA} \approx \mathrm{zPTH} 1>\mathrm{zPTH} 2$ & $(18,24)$ \\
\hline & & PLC & $\mathrm{hPTHrP} \approx \mathrm{hPTH}$ & $(18)$ \\
\hline & Seabream ${ }^{a}$ & cAMP & fPTH-L $\approx \mathrm{fPTHrPA}>\mathrm{hPTH} \approx \mathrm{bPTH}$, low respond to hPTHrP, no response to fPTH, and fPTHrPb & $(11)$ \\
\hline & & PLC & $\mathrm{fPTHrPA} \approx \mathrm{hPTHrP} \approx \mathrm{hPTH} \approx \mathrm{fPTH}-\mathrm{L} \approx \mathrm{fPTHA} \approx \mathrm{fPTHB}$, no response to fPTHrPB and bPTH & $(11)$ \\
\hline \multirow[t]{5}{*}{ PTH2R } & Human & cAMP & $\mathrm{hTIP39} \approx \mathrm{rTIP} 39 \approx \mathrm{rPTH}>\mathrm{hPTH}$ & $(53,54)$ \\
\hline & & PLC & hTIP39 $\approx$ rTIP39 > rPTH, no response to hPTH & $(53)$ \\
\hline & Rat & cAMP & hTIP39 > rPTH & $(16)$ \\
\hline & Zebrafish & cAMP & hTIP39 $\approx$ zTIP39 > hPTH & $(36)$ \\
\hline & $(S V)$ & cAMP & zTIP39 > hTIP39 & $(36)$ \\
\hline \multirow[t]{5}{*}{ PTH3R } & Chicken & cAMP & cPTHr > cPTH, low response to cPTH-L & $(17)$ \\
\hline & Zebrafish & cAMP & hPTHrP $\approx \mathrm{fPTH} \mathrm{rPA} \approx \mathrm{zPTH} 1>\mathrm{zPTH} 2>\mathrm{hPTH}$ & $(18,24)$ \\
\hline & & PLC & no response to $\mathrm{hPTHrP}$ and $\mathrm{hPTH}$ & (18) \\
\hline & Seabream ${ }^{b}$ & cAMP & fPTHrP, no response to hPTHrP and hPTH & $(20)$ \\
\hline & & PLC & no response to fPTHrP & $(20)$ \\
\hline
\end{tabular}

a Scale.

${ }^{b}$ Enterocyte.

${ }^{c}$ Extra-cellular domain.

$S V$, splice variant; $h$, human; $r$, rat; $z$, zebrafish; f, fugu; c, chicken; $x$, Xenopus.

signaling pathways, including CAMP, phospholipase C (PLC), and ERK1/2 (49). No activity has been detected for TIP39 in any mammalian PTH1R. It is interesting to note that zebrafish (zf) PTH is able to activate human PTH1R with similar potency to huPTH (24). This indicates the overall structures of the peptides and the receptor binding pockets are highly conserved from mammals to teleosts. Similar ligand specificity is observed in rodents $(16,50)$ and teleosts $(18,24)$. In teleosts, fugu (fu) PTHrPA, huPTHrP, and zfPTH exhibit similar efficacies for cAMP activation in zfPTH1R. The only exceptional case is chicken: $\mathrm{PTH} 1 \mathrm{R}$ can be activated by chicken (c) PTHrP as well as by huPTH with similar potency, but to a lower extent by cPTH and cPTH-L $(17,18,24)$.

Regarding PTH2R, TIP39 was shown to be the native ligand of PTH2R in mammals and zebrafish $(16,36,53,54)$. huPTH2R responded similarly to TIP39 and PTH in cAMP activation, but PTHs were less effective in PLC activation (53). As was the case for PTH1R, cross-species ligand reactivity is found in zPPTH2R; huTIP39 has similar potency to the endogenous ligand. In contrast, activation of the PLC has not been reported in PTH3R studies. Treatment of zfPTH3R with huPTHrP or PTH did not result in PLC stimulation, and consistent results were observed on treatment of seabream PTH3R with fuPTHrP $(18,20)$. The ligand bias of PTH3R varies in different species. zfPTH3R shows a preference for fuPTHrP over huPTH, whereas chPTH3R responds similarly to chicken PTHrP and PTH $(17,18)$. For seabream PTH3R, only fuPTHrPA could activate the receptor (20). In summary, characterization of the PTHR family in various species shows that their ligand specificity is well conserved. Cross-species ligand reactivity of PTHRs demonstrates that PTHRs share similar ligand-receptor binding properties that are conserved throughout vertebrate evolution.

\section{FUNCTIONAL CHANGES IN THE PTH-PTHR SYSTEM DURING VERTEBRATE EVOLUTION}

Due to the discovery of the relieving effect of PTH and PTHrP on tetany resulted from parathyroidectomy (12), and also that PTH and PTHrP are related to humoral hypercalcemic syndrome (55-57), initial investigations described the PTH peptides as endocrine hypercalcemic factors. Later research on PTHrP and TIP39 explored other possible physiological functions of these peptides. The vital role of PTHrP in fetal bone development was demonstrated in mouse models by deletion of the PTHrP gene and knockout of PTH1R (58-60). Much work has been undertaken to determine the wider physiological importance of PTHrP and has indicated that PTHrP is a multifunctional paracrine/autocrine factor (61). So far, in placental mammals, 
accumulated knowledge of the widespread PTH/PTHrP-PTH1R system implicates its pleiotropic functions in regulation of calcium levels including: (1) the control of the release of calcium from bone and increase in renal calcium reabsorption; (2) its effect in the development of bone, cartilage $(62-64)$, pancreas $(65,66)$, tooth (67-70), and mammary gland (62); and (3) its function to regulate placental calcium supply to the fetus $(63,64,71)$. In addition, the C-terminal regions of PTH and PTHrP were postulated to interact with other yet-to-identify receptors, with potential functions remain to be explored (72-74). On the other hand, the expression of PTH2R is restricted to the central nervous system, and the TIP39-PTH2R system is involved in nociceptive signal processing, regulation of hormonal release from the hypothalamus-pituitary axis, and modulation of affective behaviors (44). The distinct and diverse functions of these peptides observed in mammals raised the question of what are the ancestral functions of the PTH-like system in non-mammalian vertebrates and even in invertebrates. Unfortunately, the physiological functions of most PTH peptides in non-mammalian species have not been investigated in depth, and functions of these peptides are largely proposed based on the spatial distribution of their proteins and mRNAs.

The evolution of the parathyroid gland was a key event in the emergence of the tetrapods. Therefore, the expression of PTH in the parathyroid gland was originally linked to an evolutionary concept that the emergence of the PTH-PTHR system was coevolved with the adaptive transition from calcium-rich aquatic to calcium-deficient terrestrial habitats $(9,75)$. However, the unexpected identification of PTH in teleosts completely changed this view. Now, the cloning of two PTHs from elephant shark confirms that PTH-like peptides were present far back in evolution as cartilaginous fish, suggesting the original role of these peptides is unrelated to bone formation (29). The endocrine action of PTH released from parathyroid glands in mammals could not be observed in fish, which have no parathyroid gland. Instead, it was suggested that PTH is a paracrine factor in non-mammalian vertebrates such as fish and Xenopus (10). Although the function of PTH in fish remains poorly described, PTH-L which is absent from placental mammals, was proposed to mimic the role of mammalian PTH in fish, since fuPTH-L was found to be a potent factor causing whole body calcium influx in seabream larvae but no response was detected using fugu PTHA or PTHB (11). Based on the recent characterization of PTH-L from chicken and Xenopus, it was hypothesized that there was a functional transition between PTH-L and PTH during vertebrate evolution. In this scenario, PTH-L gradually lost its calcitropic activity and eventually was lost in mammalian genomes, while PTH replaced PTH-L in mammals to become the main endocrine regulator of calcium with expression restricted only to the parathyroid gland (10). One piece of supporting evidence for such a transition is that $\mathrm{PTH}-\mathrm{L}$ and PTHrP in chicken and Xenopus show overlapping tissue distributions, indicating redundancy. Similarly, immunohistochemistry in elephant shark showed that the PTH orthologs ,PTH1 and PTH2, exhibit widespread localization and considerable locational overlap with PTHrP (29). This implies that PTH-like peptides in non-mammalian vertebrates and cartilaginous fish may partially share their physiological role(s) with PTHrP. However, there is a mismatch between the results of widespread protein detection and restricted mRNA expression of elephant shark PTH1 and PTH2 (29). Whether this reflects the endocrine action of the two peptides remains to be determined.

Phylogenetic analysis of two predicted PTH-like in the lamprey genome, TIP39 and PTHrP, suggests that these are probably the ancestral members of the PTH peptide family found in vertebrates (17). In general, the expression of these two peptides appears to be unchanged in the vertebrate lineage (76). Unfortunately, no experiments have been conducted to determine expression patterns of lamprey TIP39. Wide tissue expression of PTHrP was observed in all investigated species to date, and its detection in skin, skeletal and, cardiac muscle, and kidney is conserved from lamprey to human $(9,29,77,78)$. The very similar tissue expression patterns of TIP39 and PTHrP in zebrafish and lamprey respectively indicate that TIP39 and PTHrP possess ancestral functions compared with PTH and PTH-L. In invertebrates, use of heterologous antisera in immunohistochemistry enabled detection of PTH-like peptides in snail, cockroach, and amphioxus neural tissue (79). This indicates that the origin of the PTH family may be far earlier in evolution than our expectation.

\section{CONCLUSION}

Based on bioinformatics, the presence of PTHR dates back to an ancestor before the deuterostome-protostome split. Although the true identity of PTH-like peptides in invertebrates requires clarification, the peptide family likely co-evolved with its cognate receptors in vertebrates since agnatha. Duplication of this ancestral PTHR through 2WGD resulted in the PTHR family found in modern jawed vertebrate species. Insight from the recent characterization of PTH and the PTHR family from non-mammalian species, and the discovery of putative PTHR-like and PTH-like, in a lamprey genome, reveals that the pioneer of the PTH-PTHR system, and its physiological properties, are likely fundamentally conserved throughout vertebrate evolution.

\section{ACKNOWLEDGMENTS}

The present study was supported by the HK Government RGC HKU/CRF/11G to BC and 770212 and 17112014 to LL.

\section{REFERENCES}

1. Tucci J, Russell A, Senior PV, Fernley R, Ferraro T, Beck F. The expression of parathyroid hormone and parathyroid hormone-related protein in developing rat parathyroid glands. J Mol Endocrinol (1996) 17:149-57. doi:10.1677/jme.0. 0170149

2. Harvey S, Hayer S, Sloley BD. Parathyroid hormone-induced dopamine turnover in the rat medial basal hypothalamus. Peptides (1993) 14:269-74. doi:10.1016/ 0196-9781(93)90041-E

3. Fraser RA, Kronenberg HM, Pang PK, Harvey S. Parathyroid hormone messenger ribonucleic acid in the rat hypothalamus. Endocrinology (1990) 127:2517-22. doi:10.1210/endo-127-5-2517

4. Weir EC, Brines ML, Ikeda K, Burtis WJ, Broadus AE, Robbins RJ. Parathyroid hormone-related peptide gene is expressed in the mammalian central nervous system. Proc Natl Acad Sci USA (1990) 87:108-12. doi:10.1073/pnas.87.1.108

5. Schipani E, Provot S. PTHrP, PTH, and the PTH/PTHrP receptor in endochondral bone development. Birth Defects Res C Embryo Today (2003) 69:352-62. doi:10.1002/bdrc.10028

6. Piserchio A, Usdin T, Mierke DF. Structure of tuberoinfundibular peptide of 39 residues. J Biol Chem (2000) 275:27284-90. doi:10.1074/jbc.M003869200

7. Dobolyi A, Palkovits M, Usdin TB. Expression and distribution of tuberoinfundibular peptide of 39 residues in the rat central nervous system. J Comp Neurol (2003) 455:547-66. doi:10.1002/cne.10515 
8. Dobolyi A, Dimitrov E, Palkovits M, Usdin TB. The neuroendocrine functions of the parathyroid hormone 2 receptor. Front Endocrinol (2012) 3:121. doi:10.3389/fendo.2012.00121

9. Guerreiro PM, Renfro JL, Power DM, Canario AV. The parathyroid hormone family of peptides: structure, tissue distribution, regulation, and potential functional roles in calcium and phosphate balance in fish. Am J Physiol Regul Integr Comp Physiol (2007) 292:R679-96. doi:10.1152/ajpregu.00480.2006

10. Pinheiro PL, Cardoso JC, Gomes AS, Fuentes J, Power DM, Canario AV. Gene structure, transcripts and calciotropic effects of the PTH family of peptides in Xenopus and chicken. BMC Evol Biol (2010) 10:373. doi:10.1186/1471-214810-373

11. Canario AV, Rotllant J, Fuentes J, Guerreiro PM, Rita Teodosio H, Power DM, et al. Novel bioactive parathyroid hormone and related peptides in teleost fish. FEBS Lett (2006) 580:291-9. doi:10.1016/j.febslet.2005.12.023

12. Collip JB. The extraction of a parathyroid hormone which will prevent or control parathyroid tetany and which regulates the level of blood calcium. J Biol Chem (1925) 63:395-438.

13. Boothby WM. The parathyroid glands: a review of the literature. Endocrinology (1921) 5:403-40. doi:10.1210/endo-5-4-403

14. Juppner H, Abou-Samra AB, Freeman M, Kong XF, Schipani E, Richards J, et al. A $G$ protein-linked receptor for parathyroid hormone and parathyroid hormonerelated peptide. Science (1991) 254:1024-6. doi:10.1126/science.1658941

15. Usdin TB, Gruber C, Bonner TI. Identification and functional expression of a receptor selectively recognizing parathyroid hormone, the PTH2 receptor. J Biol Chem (1995) 270:15455-8. doi:10.1074/jbc.270.26.15455

16. Usdin TB, Hoare SR, Wang T, Mezey E, Kowalak JA. TIP39: a new neuropeptide and PTH2-receptor agonist from hypothalamus. Nat Neurosci (1999) 2:941-3. doi:10.1038/14724

17. Pinheiro PL, Cardoso JC, Power DM, Canario AV. Functional characterization and evolution of PTH/PTHrP receptors: insights from the chicken. BMC Evol Biol (2012) 12:110. doi:10.1186/1471-2148-12-110

18. Rubin DA, Juppner H. Zebrafish express the common parathyroid hormone/parathyroid hormone-related peptide receptor (PTH1R) and a novel receptor (PTH3R) that is preferentially activated by mammalian and fugufish parathyroid hormone-related peptide. J Biol Chem (1999) 274:28185-90. doi:10.1074/jbc.274.40.28185

19. Rubin DA, Hellman P, Zon LI, Lobb CJ, Bergwitz C, Juppner H. A G proteincoupled receptor from zebrafish is activated by human parathyroid hormone and not by human or teleost parathyroid hormone-related peptide. Implications for the evolutionary conservation of calcium-regulating peptide hormones. J Biol Chem (1999) 274:23035-42.

20. Rotllant J, Guerreiro PM, Redruello B, Fernandes H, Apolonia L, Anjos L, et al. Ligand binding and signalling pathways of PTH receptors in sea bream (Sparus auratus) enterocytes. Cell Tissue Res (2006) 323:333-41. doi:10.1007/s00441005-0070-7

21. Cardoso JC, Felix RC, Power DM. Nematode and arthropod genomes provide new insights into the evolution of class 2 B1 GPCRs. PLoS One (2014) 9:e92220. doi:10.1371/journal.pone.0092220

22. Hwang JI, Moon MJ, Park S, Kim DK, Cho EB, Ha N, et al. Expansion of secretinlike $\mathrm{G}$ protein-coupled receptors and their peptide ligands via local duplications before and after two rounds of whole-genome duplication. Mol Biol Evol (2013) 30:1119-30. doi:10.1093/molbev/mst031

23. Ng SY, Chow BK, Kasamatsu J, Kasahara M, Lee LT, Agnathan VIP. PACAP and their receptors: ancestral origins of today's highly diversified forms. PLoS One (2012) 7:e44691. doi:10.1371/journal.pone.0044691

24. Gensure RC, Ponugoti B, Gunes Y, Papasani MR, Lanske B, Bastepe M, et al. Identification and characterization of two parathyroid hormone-like molecules in zebrafish. Endocrinology (2004) 145:1634-9. doi:10.1210/en.2003-0964

25. Venkatesh B, Kirkness EF, Loh YH, Halpern AL, Lee AP, Johnson J, et al. Survey sequencing and comparative analysis of the elephant shark (Callorhinchus milii) genome. PLoS Biol (2007) 5:e101. doi:10.1371/journal.pbio.0050101

26. Venkatesh B, Kirkness EF, Loh YH, Halpern AL, Lee AP, Johnson J, et al. Ancient noncoding elements conserved in the human genome. Science (2006) 314:1892. doi:10.1126/science. 1130708

27. Wolfe KH. Yesterday's polyploids and the mystery of diploidization. Nat Rev Genet (2001) 2:333-41. doi:10.1038/35072009

28. Jaillon O, Aury JM, Brunet F, Petit JL, Stange-Thomann N, Mauceli E, et al. Genome duplication in the teleost fish Tetraodon nigroviridis reveals the early vertebrate proto-karyotype. Nature (2004) 431:946-57. doi:10.1038/ nature 03025

29. Liu Y, Ibrahim AS, Tay BH, Richardson SJ, Bell J, Walker TI, et al. Parathyroid hormone gene family in a cartilaginous fish, the elephant shark (Callorhinchus milii). J Bone Miner Res (2010) 25:2613-23. doi:10.1002/jbmr.178

30. Cardoso JC, Pinto VC, Vieira FA, Clark MS, Power DM. Evolution of secretin family GPCR members in the metazoa. BMC Evol Biol (2006) 6:108. doi:10. 1186/1471-2148-6-108

31. Mirabeau O, Joly JS. Molecular evolution of peptidergic signaling systems in bilaterians. Proc Natl Acad Sci U S A (2013) 110:E2028-37. doi:10.1073/pnas. 1219956110

32. Ingleton PM. Parathyroid hormone-related protein in lower vertebrates. Comp Biochem Physiol B Biochem Mol Biol (2002) 132:87-95. doi:10.1016/S10964959(01)00536-X

33. Philbrick WM, Wysolmerski JJ, Galbraith S, Holt E, Orloff JJ, Yang KH, et al. Defining the roles of parathyroid hormone-related protein in normal physiology. Physiol Rev (1996) 76:127-73.

34. Ingleton PM, Danks JA. Distribution and functions of parathyroid hormonerelated protein in vertebrate cells. Int Rev Cytol (1996) 166:231-80. doi:10.1016/ S0074-7696(08)62510-3

35. Abbink W, Flik G. Parathyroid hormone-related protein in teleost fish. Gen Comp Endocrinol (2007) 152:243-51. doi:10.1016/j.ygcen.2006.11.010

36. Papasani MR, Gensure RC, Yan YL, Gunes Y, Postlethwait JH, Ponugoti B, et al. Identification and characterization of the zebrafish and fugu genes encoding tuberoinfundibular peptide 39. Endocrinology (2004) 145:5294-304 doi:10.1210/en.2004-0159

37. John MR, Arai M, Rubin DA, Jonsson KB, Juppner H. Identification and characterization of the murine and human gene encoding the tuberoinfundibular peptide of 39 residues. Endocrinology (2002) 143:1047-57. doi:10.1210/endo. 143.3 .8698

38. Moseley JM, Gillespie MT. Parathyroid hormone-related protein. Crit Rev Clin Lab Sci (1995) 32:299-343. doi:10.3109/10408369509084687

39. Blind E, Raue F, Knappe V, Schroth J, Ziegler R. Cyclic AMP formation in rat bone and kidney cells is stimulated equally by parathyroid hormone-related protein (PTHrP) 1-34 and PTH 1-34. Exp Clin Endocrinol (1993) 101:150-5. doi:10.1055/s-0029-1211222

40. Neer RM, Arnaud CD, Zanchetta JR, Prince R, Gaich GA, Reginster JY, et al. Effect of parathyroid hormone (1-34) on fractures and bone mineral density in postmenopausal women with osteoporosis. N Engl J Med (2001) 344:1434-41. doi:10.1056/NEJM200105103441904

41. Moen MD, Scott LJ. Recombinant full-length parathyroid hormone (1-84). Drugs (2006) 66:2371-81. doi:10.2165/00003495-200666180-00008

42. Potetinova Z, Barbier JR, Suen T, Dean T, Gardella TJ, Willick GE. Cterminal analogues of parathyroid hormone: effect of C-terminus function on helical structure, stability, and bioactivity. Biochemistry (2006) 45:11113-21. doi:10.1021/bi060500q

43. Dean T, Khatri A, Potetinova Z, Willick GE, Gardella TJ. Role of amino acid side chains in region 17-31 of parathyroid hormone (PTH) in binding to the PTH receptor. J Biol Chem (2006) 281:32485-95. doi:10.1074/jbc.M606179200

44. Dobolyi A, Palkovits M, Usdin TB. The TIP39-PTH2 receptor system: unique peptidergic cell groups in the brainstem and their interactions with central regulatory mechanisms. Prog Neurobiol (2010) 90:29-59. doi:10.1016/j.pneurobio. 2009.10.017

45. Hoare SR, Usdin TB. Molecular mechanisms of ligand recognition by parathyroid hormone 1 (PTH1) and PTH2 receptors. Curr Pharm Des (2001) 7:689-713. doi: $10.2174 / 1381612013397825$

46. Hoare SR, Clark JA, Usdin TB. Molecular determinants of tuberoinfundibular peptide of 39 residues (TIP39) selectivity for the parathyroid hormone-2 (PTH2) receptor: N-terminal truncation of TIP39 reverses PTH2 receptor/PTH1 receptor binding selectivity. J Biol Chem (2000) 275:27274-83. doi:10.1074/jbc.M003910200

47. Gardella TJ, Luck MD, Jensen GS, Usdin TB, Juppner H. Converting parathyroid hormone-related peptide (PTHrP) into a potent $\mathrm{PTH}-2$ receptor agonist. J Biol Chem (1996) 271:19888-93. doi:10.1074/jbc.271.33.19888

48. Rotllant J, Redruello B, Guerreiro PM, Fernandes H, Canario AV, Power DM. Calcium mobilization from fish scales is mediated by parathyroid hormone related protein via the parathyroid hormone type 1 receptor. Regul Pept (2005) 132:33-40. doi:10.1016/j.regpep.2005.08.004 
49. Juppner H. Receptors for parathyroid hormone and parathyroid hormonerelated peptide: exploration of their biological importance. Bone (1999) 25:87-90. doi:10.1016/S8756-3282(99)00110-6

50. McDonald IM, Austin C, Buck IM, Dunstone DJ, Gaffen J, Griffin E, et al. Discovery and characterization of novel, potent, non-peptide parathyroid hormone-1 receptor antagonists. J Med Chem (2007) 50:4789-92. doi:10.1021/jm0707626

51. Cupp ME, Nayak SK, Adem AS, Thomsen WJ. Parathyroid hormone (PTH) and PTH-related peptide domains contributing to activation of different PTH receptor-mediated signaling pathways. J Pharmacol Exp Ther (2013) 345:404-18. doi:10.1124/jpet.112.199752

52. Pioszak AA, Parker NR, Gardella TJ, Xu HE. Structural basis for parathyroid hormone-related protein binding to the parathyroid hormone receptor and design of conformation-selective peptides. J Biol Chem (2009) 284:28382-91. doi:10.1074/jbc.M109.022905

53. Della Penna K, Kinose F, Sun H, Koblan KS, Wang H. Tuberoinfundibular peptide of 39 residues (TIP39): molecular structure and activity for parathyroid hormone 2 receptor. Neuropharmacology (2003) 44:141-53. doi:10.1016/S00283908(02)00335-0

54. Usdin TB, Hilton J, Vertesi T, Harta G, Segre G, Mezey E. Distribution of the parathyroid hormone 2 receptor in rat: immunolocalization reveals expression by several endocrine cells. Endocrinology (1999) 140:3363-71. doi:10.1210/en. 140.7.3363

55. Strewler GJ, Williams RD, Nissenson RA. Human renal carcinoma cells produce hypercalcemia in the nude mouse and a novel protein recognized by parathyroid hormone receptors. J Clin Invest (1983) 71:769-74. doi:10.1172/JCI110825

56. Stewart AF, Insogna KL, Goltzman D, Broadus AE. Identification of adenylate cyclase-stimulating activity and cytochemical glucose-6-phosphate dehydrogenase-stimulating activity in extracts of tumors from patients with humoral hypercalcemia of malignancy. Proc Natl Acad Sci U S A (1983) 80:1454-8. doi:10.1073/pnas.80.5.1454

57. Rodan SB, Insogna KL, Vignery AM, Stewart AF, Broadus AE, D’Souza SM, et al. Factors associated with humoral hypercalcemia of malignancy stimulate adenylate cyclase in osteoblastic cells. J Clin Invest (1983) 72:1511-5. doi:10.1172/JCI111108

58. Lanske B, Divieti P, Kovacs CS, Pirro A, Landis WJ, Krane SM, et al. The parathyroid hormone $(\mathrm{PTH}) / \mathrm{PTH}$-related peptide receptor mediates actions of both ligands in murine bone. Endocrinology (1998) 139:5194-204. doi:10.1210/endo. 139.12.6361

59. Lanske B, Karaplis AC, Lee K, Luz A, Vortkamp A, Pirro A, et al. PTH/PTHrP receptor in early development and Indian hedgehog-regulated bone growth. Science (1996) 273:663-6. doi:10.1126/science.273.5275.663

60. Karaplis AC, Luz A, Glowacki J, Bronson RT, Tybulewicz VL, Kronenberg HM, et al. Lethal skeletal dysplasia from targeted disruption of the parathyroid hormone-related peptide gene. Genes Dev (1994) 8:277-89. doi:10.1101/gad. 8.3.277

61. McCauley LK, Martin TJ. Twenty-five years of PTHrP progress: from cancer hormone to multifunctional cytokine. J Bone Miner Res (2012) 27:1231-9. doi:10.1002/jbmr.1617

62. Wysolmerski JJ, McCaughern-Carucci JF, Daifotis AG, Broadus AE, Philbrick WM. Overexpression of parathyroid hormone-related protein or parathyroid hormone in transgenic mice impairs branching morphogenesis during mammary gland development. Development (1995) 121:3539-47.

63. Wu TL, Vasavada RC, Yang K, Massfelder T, Ganz M, Abbas SK, et al. Structural and physiologic characterization of the mid-region secretory species of parathyroid hormone-related protein. J Biol Chem (1996) 271:24371-81. doi:10.1074/jbc.271.40.24371

64. Care AD, Abbas SK, Pickard DW, Barri M, Drinkhill M, Findlay JB, et al. Stimulation of ovine placental transport of calcium and magnesium by mid-molecule fragments of human parathyroid hormone-related protein. Exp Physiol (1990) 75:605-8. doi:10.1113/expphysiol.1990.sp003437

65. Guthalu Kondegowda N, Joshi-Gokhale S, Harb G, Williams K, Zhang XY, Takane KK, et al. Parathyroid hormone-related protein enhances human ss-cell proliferation and function with associated induction of cyclin-dependent kinase 2 and cyclin E expression. Diabetes (2010) 59:3131-8. doi:10.2337/db09-1796

66. Cebrian A, Garcia-Ocana A, Takane KK, Sipula D, Stewart AF, Vasavada RC. Overexpression of parathyroid hormone-related protein inhibits pancreatic beta-cell death in vivo and in vitro. Diabetes (2002) 51:3003-13. doi:10.2337/ diabetes.51.10.3003
67. Ouyang H, McCauley LK, Berry JE, Saygin NE, Tokiyasu Y, Somerman MJ. Parathyroid hormone-related protein regulates extracellular matrix gene expression in cementoblasts and inhibits cementoblast-mediated mineralization in vitro. J Bone Miner Res (2000) 15:2140-53. doi:10.1359/jbmr. 2000.15.11.2140

68. Ouyang H, McCauley LK, Berry JE, D’Errico JA, Strayhorn CL, Somerman MJ. Response of immortalized murine cementoblasts/periodontal ligament cells to parathyroid hormone and parathyroid hormone-related protein in vitro. Arch Oral Biol (2000) 45:293-303. doi:10.1016/S0003-9969(99)00142-9

69. Philbrick WM, Dreyer BE, Nakchbandi IA, Karaplis AC. Parathyroid hormonerelated protein is required for tooth eruption. Proc Natl Acad Sci U S A (1998) 95:11846-51. doi:10.1073/pnas.95.20.11846

70. Tenorio D, Hughes FJ. An immunohistochemical investigation of the expression of parathyroid hormone receptors in rat cementoblasts. Arch Oral Biol (1996) 41:299-305. doi:10.1016/0003-9969(95)00113-1

71. Rodda CP, Kubota M, Heath JA, Ebeling PR, Moseley JM, Care AD, et al. Evidence for a novel parathyroid hormone-related protein in fetal lamb parathyroid glands and sheep placenta: comparisons with a similar protein implicated in humoral hypercalcaemia of malignancy. J Endocrinol (1988) 117:261-71. doi:10.1677/joe.0.1170261

72. Valin A, Guillen C, Esbrit P. C-terminal parathyroid hormone-related protein (PTHrP) (107-139) stimulates intracellular $\mathrm{Ca}(2+)$ through a receptor different from the type 1 PTH/PTHrP receptor in osteoblastic osteosarcoma UMR 106 cells. Endocrinology (2001) 142:2752-9. doi:10.1210/en.142.7.2752

73. Divieti P, Inomata N, Chapin K, Singh R, Juppner H, Bringhurst FR. Receptors for the carboxyl-terminal region of pth(1-84) are highly expressed in osteocytic cells. Endocrinology (2001) 142:916-25. doi:10.1210/en.142.2.916

74. Inomata N, Akiyama M, Kubota N, Juppner H. Characterization of a novel parathyroid hormone $(\mathrm{PTH})$ receptor with specificity for the carboxyl-terminal region of PTH-(1-84). Endocrinology (1995) 136:4732-40. doi:10.1210/endo. 136.11.7588200

75. Bouillon R, Suda T. Vitamin D: calcium and bone homeostasis during evolution. Bonekey Rep (2014) 3:480. doi:10.1038/bonekey.2013.214

76. Bhattacharya P, Yan YL, Postlethwait J, Rubin DA. Evolution of the vertebrate pth2 (tip39) gene family and the regulation of PTH type 2 receptor (pth2r) and its endogenous ligand pth2 by hedgehog signaling in zebrafish development. J Endocrinol (2011) 211:187-200. doi:10.1530/JOE-10-0439

77. Trivett MK, Potter IC, Power G, Zhou H, Macmillan DL, Martin TJ, et al. Parathyroid hormone-related protein production in the lamprey Geotria australis: developmental and evolutionary perspectives. Dev Genes Evol (2005) 215:553-63. doi:10.1007/s00427-005-0015-x

78. Danks JA, Trivett MK, Power DM, Canario AV, Martin TJ, Ingleton PM. Parathyroid hormone-related protein in lower vertebrates. Clin Exp Pharmacol Physiol (1998) 25:750-2. doi:10.1111/j.1440-1681.1998.tb02290.x

79. Hull KL, Fathimani K, Sharma P, Harvey S. Calcitropic peptides: neural perspectives. Comp Biochem Physiol C Pharmacol Toxicol Endocrinol (1998) 119:389-410. doi:10.1016/S0742-8413(98)00010-3

Conflict of Interest Statement: The authors declare that the research was conducted in the absence of any commercial or financial relationships that could be construed as a potential conflict of interest. The Associate Editor Hubert Vaudry declares that, despite having collaborated with author Billy K. C. Chow, the review process was handled objectively and no conflict of interest exists.

Received: 18 December 2014; paper pending published: 09 February 2015; accepted: 17 February 2015; published online: 10 March 2015.

Citation: On JSW, Chow BKC and Lee LTO (2015) Evolution of parathyroid hormone receptor family and their ligands in vertebrate. Front. Endocrinol. 6:28. doi: $10.3389 /$ fendo.2015.00028

This article was submitted to Neuroendocrine Science, a section of the journal Frontiers in Endocrinology.

Copyright (c) 2015 On, Chow and Lee. This is an open-access article distributed under the terms of the Creative Commons Attribution License (CC BY). The use, distribution or reproduction in other forums is permitted, provided the original author(s) or licensor are credited and that the original publication in this journal is cited, in accordance with accepted academic practice. No use, distribution or reproduction is permitted which does not comply with these terms. 